\title{
The Brand Internationalization of Chinese Sportswear Companies: A Case Study of Anta and Li-Ning
}

\author{
Chengzhi Niu, ${ }^{1, *}$ \\ ${ }^{1}$ Beijing institute of fashion technology \\ *Corresponding author. Email: Macrov@yeah.net

\begin{abstract}
This paper selects Li Ning and Anta as research cases to find out how these two companies succeed in internationalization. Through the analysis we concluded a successful path of the brand internationalization process of Chinese apparel companies, and also provide a reference for other Chinese apparel companies to promote internationalization.
\end{abstract}

Keywords: brand internationalization, Li Ning, Anta

\section{INTRODUCTION}

As the world's largest apparel producer and exporter, China maintains a significant competitive advantage in terms of apparel manufacturing but is in a weak position in brand competition. Chinese apparel companies, most of which are originally OEM (Original Equipment Manufacturing) producers, find it very hard to establish their own brand in the global market.

In resent years, two Chinese sportswear brands caught the attention of the world fashion industry. How did they achieve it? Compared with the efforts they had done before, is there any other novel reasons behind their current success? The answer to these questions may offer a clue to the internationalization of Chinese apparel brands.

\section{LITERATURE REVIEW}

Levitt[1] (1983) first proposed the concept of "brand internationalization", but academia has not yet formed an agreed view about it (Jeryl \& Fernando, 2007)[2]. Some researchers defined brand internationalization from the perspective of brand management, stating brand internationalization is a brand management strategy to extend the same brand name, packaging, and advertising planning into different overseas markets. Jeryl and Fernando[2] (2007) studied the definition of brand internationalization in more than 40 literature and then grouped them into narrow and broad categories. They summarized that the narrow understanding of brand internationalization is taking it as a "brand name decision in the process of internationalization of enterprises", and the broad definition is a "development strategy for companies to show a positive image to target customers overseas and build corporate brand equity". From this perspective, brand internationalization is a stage of corporate internationalization and its purpose is to establish brand equity in the international market.

Some people defined brand equity as "a value premium that a company generates from a product with a recognizable name when compared to a generic equivalent". He also noted that companies can create brand equity for their products by making them memorable, easily recognizable, and superior in quality and reliability. In this light, brand equity is a brand's value that is determined by consumer perception of and experiences with the brand. Components of brand equity include brand awareness, brand experience, perceived quality, brand association, brand preference, and brand loyalty.

Given the definitions above and by reference to Daye[3] (2010), in this paper, brand internationalization is defined as a process that a brand is recognized throughout much of the world.

Discussion about brand building is based on competitiveness theories, mainly from the perspective of 
resources and capabilities companies have. Researchers believe that corporate assets, human resources capital, and social capital affect the production, research and development, distribution channels, and the communication of brand image of a company, which will help a company's brand building (Kapferer[4]). Some researchers believe that dynamic capabilities have an important impact on the formation of brand awareness and the international brand. Some researchers proposed that innovation is a fundamental means for Chinese companies to establish brands. Some researchers proposed that technological innovation is an indispensable condition for a company to build its brand. In addition, some researchers argued that due to its dual influences on innovation, marketing is the most essential factor for brand building.

With respect to brand competitiveness, some researcher believes that brand competitiveness is the unique ability for a company to differentiate itself from other brands, and is determined by a company's products, including products' quality and performance, and services. Blattberg[5] (1990) showed that new functions of a product can increase a company's brand competitiveness as long as no negative related effects arise.

Some Chinese researchers studied the transition of an OEM producer to an ODM, and even OBM producer. Dong Some researcher proposed that production technology, global marketing, brand reputation and brand localization play different roles in different stages of brand internationalization. Some researcher believed that product innovation and brand management are two essential factors for a company's shift from ODM to OBM. Some researcher also argued that knowledge acquisition, internalization and innovation determined the success of the transition from OEM to ODM.

In respect of international brand building, researchers discussed the influence factors such as cultural difference and country of origin. Some researcher proposed "brand marketing should take a more flexible approach to the needs of consumer groups in different countries". Han and Terpstra[6] (1988), Chao[7] (1993) believed that consumers judge the attributes of a product based on the origin of the product, and then form their perceptions towards a brand. From the perspective of brand management, Douglas[8] (2001) believed that product differentiation and multi-brand strategy can enhance the image of a brand, and then help to build a global brand.

To sum up, researchers discussed brand internationalization from different angles, identified some contributing factors for the building of an international brand. In this paper, we take a case study method to explore the route of Chinese apparel brands' internationalization process, try to find out the contributing factors behind this process and the influencing mechanism of these factors.

\section{ANALYSIS OF BRAND INTERNATIONALIZATION OF ANTA AND LI-NING}

With the acceleration of economic globalization and the implementation of the reform and opening-up policy, China's imports and exports of goods increased from US \$ 20.64 billion in 1978 to US \$ 4.1 trillion in 2017, with an average annual growth rate of $14.5 \%$, ranking from 30 th to 1 st in global goods trade. Despite the rapid growth in the trade volume, China is still in the middle part of the "smile curve" and trying to move to the two ends of the value chain, which demands efforts in technological innovation and marketing. In 2019, China proposed to promote the high-quality development of foreign trade. Promoting innovation, improving the quality of export products, strengthening brand building are some of the keywords in the plan.

As the world's largest apparel producer and exporter, China maintains a significant competitive advantage in terms of apparel manufacturing but is in a weak position in brand competition. There are very few well-known Chinese apparel brands in the world market. Many internationally renowned foreign apparel brands entered Chinese market and achieved good performance, while Chinese apparel companies, most of which are originally OEM (Original Equipment Manufacturing) producers, find it very hard to establish their own brand in the global market. This leads to a fact that apparel products originated from China are sold globally but few under their own brand names.

Some Chinese apparel brands started to develop overseas markets since 1990s but did not see a successful result. Although Chinese apparel brands have entered the foreign markets such as the United States, Spain, Poland, Greece, France, etc., their sales revenues derived from overseas markets were very small, and their brand awareness were very low in the foreign markets. This impedes Chinese apparel firms' expansion into wider markets and limits their profitability in a global context. How to build an international brand has become an urgent issue facing Chinese apparel companies.

In 2019, two Chinese sportswear brands caught the attention of the world fashion industry. Anta, a Fujianbased Chinese sportswear brand with 28 years history, ranked 21st in Brand Finance Apparel 50 list[9] (Brand Finance, 2019), being the only listed brand from mainland China. Another Chinese sportswear brand, Li-Ning, also 
established in 1991, presented its new collections at New York Fashion Week and won high praise.

It seems that, after more than 20 years' efforts, a couple of Chinese apparel firms finally found a way to bring their brands into the international market and seize the attention of professionals and the public from the western world. How did they achieve it? Compared with the efforts they had done before, is there any other novel reasons behind their current success? The answer to these questions may offer a clue to the internationalization of Chinese apparel brands.

The purpose of this study is to find out how Chinese apparel companies can build an international brand, so the sample companies have to be in the apparel industry and have gained brand reputation worldwide. Besides, only the sample companies compete in a very competitive market can their paths to becoming an international brand provide a reference for other brands. After screening, we selected Anta and Li-Ning as our samples.

Firstly, Anta and Li-Ning are leading local sportswear brands in China and have made initial breakthroughs on their ways towards brand internationalization. Li-Ning started its brand internationalization earlier than any local sportswear brands in China. The overseas revenues of LiNing reached more than 269 million RMB in 2019, accounting for $1.94 \%$ of its total revenue. Although this percentage is lower than the previous year, which is $2.4 \%$ for 2018 and $2.7 \%$ for 2017, Li-Ning's brand reputation has hugely increased by its fashion show in New York and Paris Fashion Week in 2018 and 2019. In 2019, Anta ranks 21st in the world's 50 most valuable clothing brands by Brand Finance, and is being selected on the "50 companies to watch in 2020" of Bloomberg intelligence, standing out among 2,000 global listed companies and become the only sportswear company being selected on the "50 Companies to Watch" list twice. Meanwhile, Anta announced in 2019 it has set up a global retail headquarters in Shanghai to speed up its globalization, planning to enter the European and American markets, and established an overseas department in Southeast Asia. Anta's objective is, in the next 5 years, overseas markets will account for $15 \%$ of corporate total revenues. Li-Ning and Anta are typical Chinese fashion brands going overseas.

Secondly, the sportswear market is a highly competitive market with highly brand concentration. Nike, Adidas, Puma, Under Amour, New Balance, Skechers, and Asics are top sportswear brands globally. Nike and Adidas together accounted for $56 \%$ of the global sportswear market in 2017, according to a research report of Wedbush, far ahead of other brands. In 2019 financial year, Nike and Adidas achieved revenues of USD 3.91 billion and USD 2.56 billion respectively, maintaining rapid growth. As the two giants of sportswear industry, Nike and Adidas are always in the top three position in major global sportswear markets while other brands such as Puma, Under Amour, Asics, etc. are striving to gain some share in certain regional markets. In a market with so many strong well-established brands, how a Chinese local sportswear brand can stand out and finally set up brand reputation worldwide is a question worth studying.

Thirdly, many researchers studied the marketing strategies of sportswear brands and found that strategies they employed to maintain or expand their market share were similar, that is, teams or games sponsorship, sports stars endorsement, inspirational brand slogan, etc. These are also replicated by Chinese sportswear brands when they initially tried to develop foreign markets. Are these strategies workable for Chinese brands to open a foreign market or build their brand awareness? If international marketing were not the only factor to help a local brand evolve to a global brand, what are the other influences for building a brand globally?

We thus selected these two brands as the samples of this study.

Since the brand value is determined by consumer perception of and experiences with the brand, so we first look at foreign consumers' comments on Anta and LiNing products. Consumers gave very positive evaluation and had good experiences with both Anta and Li-Ning products.

From consumer evaluations of Anta and Li Ning, four aspects related to the brand equity can be extracted, which constitute overseas consumers' recognition of these two brands. The products of both brands are considered to be of good quality, and the consumer 's experience with the products of these two brands, both in terms of function, design, and service, is very good, but some consumers stated problems with the size of the products. Consumers expressed their willingness to buy products again, and consumers would queue up for purchase new products of these two brands, showing consumer preferences for these two brands. When it comes to Anta and Li-Ning, consumers' main impressions are good products with high quality and low price.

Both Anta and Li-Ning launched a variety of international marketing activities these years, including advertising, sponsorship, public relations and endorsement. All these marketing activities substantially raised the brand awareness of Anta and Li-Ning. According to Ipsos, the world's leading research institution, a survey of the impact of Rio Olympic sponsorship data showed that the Olympics increased 
Anta's brand awareness by $17 \%$. At the same time, Anta's KT series products, which were launched after the signing of NBA star Klay Thompson, have been well received in the market, greatly increasing its brand awareness. For LiNing, its popularity mainly came from the display in New York and Paris Fashion Week, where it won more attention by the original attitude and stylish influence of China Li-Ning to world with theme “中國李寧” .

The data show that, in recent years, Anta and Li-Ning have released many new products, some of which are cobranded models launched with sports stars or fashion designers, such as Anta's Thompson-KT series basketball shoes and Li-Ning's "Zhang Chi You Du" limited products launched with Chinese pioneer fashion designer Zhang Chi, and some are series products launched for the sports or games, such as Li-Ning's high-end shoe product "RANGER-Chameleon" badminton shoes and Anta's special shoes for the Winter Olympic Games. They also launched limited editions with unique technology or design, such as Anta's limited-edition SHINE \& GLOW color scheme for the Berlin Marathon Expo 2019 and LiNing's "Wade Way 6" basketball shoes developed jointly with BASF in Germany Drive Foam rebound technology. Besides, Li-Ning also launched featured collections for Fashion Week. The launch of new products has greatly increased their brands' awareness and has been sought after by consumers, building consumer preferences for the brand.

Both Li Ning and Anta attach great importance to product design and research and development (R\&D). In recent years, Anta's R\&D expenditure accounted for $2.5 \%$ $-3 \%$ of its total revenue, while Li Ning's R\&D ratio has been increasing continuously since 2016, reaching $2.6 \%$ of its total revenue in 2019. Both brands have set up R\&D and design centers overseas, established international design and R\&D teams, and achieved the internationalization of R\&D and design. The increase in R\&D investment has greatly enhanced the company's technological innovation capabilities. Since 2015, the two brands have continuously introduced new technologies to improve the technological functions of their products.

Both Li Ning and Anta have adopted a multi-brand strategy. After acquiring the FILA brand in 2009, Anta also successively acquired brands such as Sprandi, Descente, Kingkow. In 2019, Anta's acquisition of Amer Sports attracted wide attention. These brand acquisition moves have increased Anta's corporate influence, especially in the sportswear industry. Compared with Anta, Li Ning acquired foreign brands earlier, but has not significant moves in recent years. On the whole, since these brand acquisitions are mainly limited to the operating rights of foreign brands in the Chinese market, they have little effect on the brand awareness of Li Ning and Anta in overseas markets.

As far as the development of overseas markets is concerned, Li Ning and Anta have not made any particularly large-scale expansion in recent years, whether they enter new overseas markets or further expand distribution channels in the existing overseas markets. Before 2008, Anta gradually opened stores in Southeast Asia, Eastern Europe, and the Middle East, and its stores grew as well, but in recent years it has not further expanded. Many overseas consumers ask on social platforms where they can buy Li-Ning and Anta products. This shows consumers 'willingness to buy, but also shows that both Li-Ning and Anta need to do more in the establishment of their distribution channels. It's worth noting that since 2019, Anta and Li-Ning have both proposed overseas market expansion plans. Based on the improvement of their brand awareness, Anta and Li Ning's market expansion strategies will enhance the purchasing experience of overseas consumers and further enhance their brands' reputation and establish brand loyalty.

\section{CONCLUSION}

Figures and tables should be placed either at the top or bottom of the page and close to the text referring to them if possible. The study on the brand internationalization of Li-Ning and Anta shows that Anta and Li-Ning have built brand equity in the international market to a certain extent, manifested as the two brands have formed good perceived quality, brand experience, brand preferences and brand associations.

In the process of establishing brand equity in foreign markets, conducting international marketing activities was an indispensable factor for Anta and Li-Ning to build their brand awareness, and launching new products strengthened their brand awareness and helped build consumer preferences for these two brands. Consumerperceived product quality and brand experience are the core equity of these two brands, which constitute consumers' association of the brands and determine the consumers' preference to the brands. The technological innovation is a core factor of for Anta and Li-Ning to improve the product quality and brand experience perceived by consumers. Brand strategy, including brand acquisition and overseas market expansion, has little effect on the establishment of brand image at the current stage of brand internationalization of Anta and Li-Ning, while with the enhancement of their brand awareness, brand strategy and overseas market expansion will help Anta and Li-Ning improve their brand image and to further build their brand loyalty. Thus, the brand 
internationalization of Anta and Li-Ning can be illustrated as Figure 1.

In the process of brand internationalization, Anta and Li-Ning are in the second phase, as shown in Figure 1. For this phase, technological innovation and product development are crucial factors for the form of brand equity, which is the reason why Anta and Li-Ning achieved their breakthroughs of brand internationalization.

Although this study discussed the contributing factors and the influencing mechanism of the brand internationalization of sportswear brands, it is still an exploratory research. Compared with other fashion products categories, sportswear products have its own features, so further research is recommended to examine the same research questions with a wider range of apparel companies to get a more deeply understanding about the process of brand internationalization of China's apparel corporations.

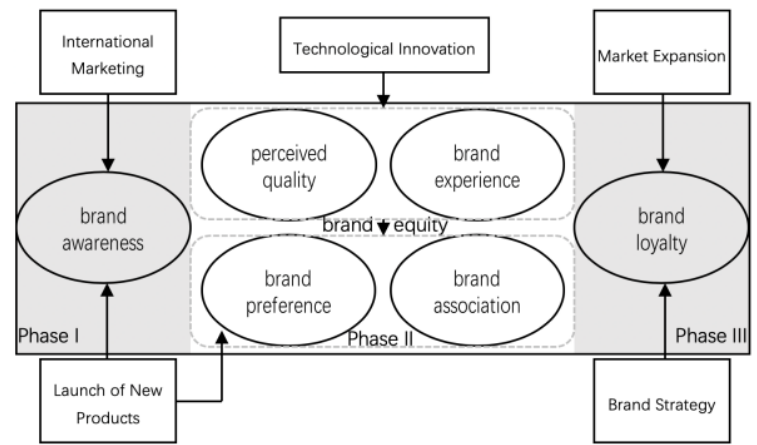

Figure 1 The route of brand internationalization of Anta and Li-Ning

\section{AUTHORS' CONTRIBUTIONS}

Chengzhi Niu performed the study and wrote the paper.

\section{ACKNOWLEDGMENTS}

We are greatly indebted to all our teachers in Business School who have helped us directly and indirectly in our studies, from whose devoted teaching and enlightening lectures we have benefited a lot and academically prepared for the thesis. Any progress that we have made is the result of their profound concern and selfless devotion.

\section{REFERENCES}

[1] Levitt T. (1983 May-June). The Globalization of markets[J]. Harvard Business Review, 92-102.and (2007). reviewing the literature[J]. International Marketing Review, 24(3):252-270.

[2] Jeryl, W. and Fernando, F.(2007). Understanding international branding: Defining the domain and reviewing the literature $[\mathrm{J}]$. International Marking Review, 24(3): 252-270.

[3] Derrick Daye.(2010, February 19). What is global brand? [OL]. Branding Strategy Insider. Retrieved [2020-03-15].brandingstrategyinsider.com/brandingjust-ask/

[4] Kapferer, J N.(1997). Strategic brand management. (2nd Ed. ) . London: Kogan Page.

[5] Blattberg, R. C. , Neslin, S. A. , \& Hall, P. . (1990). Sales promotion: concepts, methods and strategies. Englewood Cloffs, NJ: Prentice Hall.

[6] Han C M, V Terpstra.(1988). Country - of - Origin Effects for Uni - National and Bi - National Products[J]. Journal of International Business Studies, 19(2), 235-255.

[7] Chao P(1993). Partitioning country-of-origin effects: consumer evaluations of a Hybrid product[J]. Journal of international business studies, 24(1): 291 306.

[8] Douglas, S P, Craing, C S, and Nijssen, E J. (2001). Integrating branding strategy across markets: Builing international brand architecture [J]. Journal of International Marketing, 9(2): 97-114.

[9] Brand Finance Apparel 50 2019[OL]. Brand Finance, 2019-02 